\title{
The radioprotective effect of a new aminothiol (20-PRA)
}

M.F. Dolabela ${ }^{1}$ M.T.Pereira ${ }^{3}$, C.E. Salas ${ }^{2}$, G.M. Steffani ${ }^{3}$, D.L. Nelson ${ }^{4}$,

D. Piló-Veloso ${ }^{3}$ and M.T.P. Lopes ${ }^{1}$

\author{
Departamentos de ${ }^{1}$ Farmacologia, ${ }^{2}$ Bioquímica e Imunologia, \\ Instituto de Ciências Biológicas, ${ }^{3}$ Química, Instituto de Ciências Exatas and \\ ${ }^{4}$ Faculdade de Farmácia, Universidade Federal de Minas Gerais, \\ Belo Horizonte, MG, Brasil
}

\section{Correspondence \\ C.E. Salas \\ Departamento de Bioquímica e Imunologia, ICB, UFMG \\ Av. Antonio Carlos, 6627 \\ 31270-901 Belo Horizonte, MG \\ Brasil \\ E-mail: cesbufmg@mono.icb.ufmg.br \\ Research supported by FAPEMIG (Nos. CBS 666/91 and CBS 21198/ 95) and CNPq (Nos. 400190/93-1 and 523304/94-3).}

\section{Abstract}

We examined the radioprotective effect of aminothiol 2-Npropylamine-cyclo-hexanethiol (20-PRA) on a human leukemic cell line (K562) following various radiation doses (5, 7.5 and $20 \mathrm{~Gy}$ ) using a source of ${ }^{60} \mathrm{Co} \gamma$-rays. At 5 Gy and $1 \mathrm{nM} 20$-PRA, a substantial protective effect $(58 \%)$ was seen $24 \mathrm{~h}$ after irradiation, followed by a decrease at $48 \mathrm{~h}(11 \%)$. At the high radiation dose (20 Gy) a low protective effect was also seen (35\%). In addition, the antitumorigenic potential of $10 \mathrm{nM} 20$-PRA was shown by the inhibition of crown gall formation induced by Agrobacterium tumefaciens. The radioprotective potency of 20-PRA is $10^{5}-10^{6}$ times higher than that of the aminothiol WR-1065 (N-(2-mercaptoethyl)-1,3-diaminopropane) whose protective effect is in the 0.1 to $1.0 \mathrm{mM}$ range.
Key words

- Aminothiols

- Cytotoxic effect

- Radioprotector

- Antitumorigenic effect
Aminothiols have been the subject of considerable research because of their reported ability to protect tissues against acute damage induced by either ionizing radiation or alkylating cytotoxic agents (1). However, because of their mutagenic and carcinogenic potential, the clinical application of these agents increases the risk of secondary tumors in treated patients (2).

Aminothiols have also been cited as protective agents against the induction of sublethal mutagenic, transforming and carcinogenic effects by free radicals $(3,4)$. There are reports showing that the aminothiol WR2721 (S-2-(3-aminopropylamino) ethylphosphorothioic acid) can inhibit the development of radiation-induced sarcoma (5) and that $\mathrm{N}$-acetyl-L cysteine inhibits hepatocar- cinoma induced by $\mathrm{N}-2$-acetylaminofluorene (6). These results, together with others, support the protective role for aminothiols (7).

Several mechanisms have been proposed to explain radioprotection by aminothiols, including induction of hypoxia (8), scavenging of free radicals (9), protection of nucleic acid against free radicals (10), delayed repair of DNA strand breaks (11-13), increased cystine uptake (14) and glutathione biosynthesis (13). The use of radioprotective drugs in humans has been severely limited by the toxicity of the compounds synthesized earlier (15). This situation prompted the US Army to sponsor a program for the synthesis of compounds with radioprotective potential (16). One of these compounds (WR-2721) has been extensively investigated because of 
its reported radioprotective capacity (1).

In the present study, we evaluated the radioprotective properties of a newly synthesized non-phosphorylated aminothiol. 20PRA (2-N-propylamine-cyclo-hexanethiol) was synthesized by reacting propylamine dissolved in benzene with epithio-cyclo-hexane. The endpoint of the reaction ( $24 \mathrm{~h}$ ) was monitored by the exhaustion of epithio-cyclohexane using infrared spectrometry. Excess amine and solvent were removed by fractioned distillation. The purity of 20-PRA used in this study was checked by gas chromatography coupled to mass spectrometry. 20-PRA was freshly dissolved in $1 \mathrm{mM}$ dimethylsulfoxide (DMSO) prior to use.

In preliminary experiments, we analyzed the toxicity of 20-PRA using the brine shrimp assay (17). 20-PRA (1 to $100 \mu \mathrm{M}$ ) dissolved in $10 \mathrm{mM} \mathrm{DMSO}$ was added to metanauplius larvae of Artemia salina to determine the

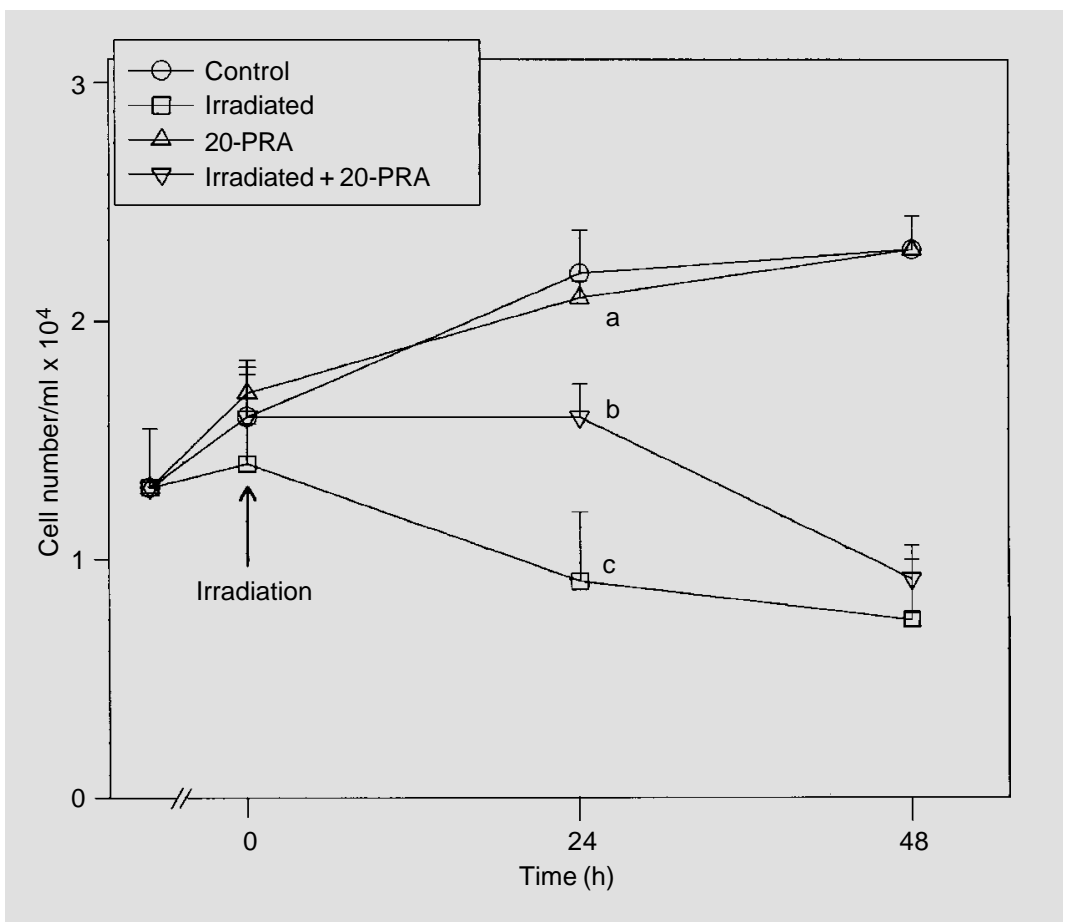

Figure 1 - The radioprotective effect of 20-PRA on K562 cells. Cells were incubated for 30 min with $1 \mathrm{nM} 20-\mathrm{PRA}$ and then irradiated with $5 \mathrm{~Gy}$. After irradiation, the cells were incubated for $48 \mathrm{~h}$. The viable cell number was determined by the Trypan blue technique. Data are reported as mean $\pm \mathrm{SEM}$ for $\mathrm{N}=3-7$ experiments. a vs $\mathrm{b}, \mathrm{P}=0.07$; a vs $\mathrm{c}, \mathrm{P}=0.005$; b vs $\mathrm{c}, \mathrm{P}=0.02$ measured by the Student- $t$ test. survival rate following a 24-h incubation period. The appropriate controls without aminothiol were used to establish the effect of DMSO. The lethal concentration of $50 \%$ $\left(\mathrm{LC}_{50}\right)$ calculated by the PROBIT test (18) was $50 \mu \mathrm{M}$ (data not shown).

Once the $\mathrm{LC}_{50}$ was established, we tested the radioprotective effect of 20-PRA on K562 cells, a human leukemic cell line provided by Dr. R. Brentani (Instituto Ludwig de Pesquisa sobre o Câncer) grown in RPMI 1640 supplemented with 5\% FBS (fetal bovine serum). The survival rate was determined upon the addition of 20-PRA ( $1 \mathrm{nM}$ to $10 \mu \mathrm{M})$ to exponentially growing K562 cells $\left(1.5 \times 10^{4}\right.$ cells $\left./ \mathrm{ml}\right)$ between $0-48 \mathrm{~h}$ in a cell incubator at $37^{\circ} \mathrm{C}$ supplied with $3 \% \mathrm{CO}_{2}$. The number of viable cells was determined by the Trypan blue dye exclusion test using a Neubauer chamber. 20-PRA $(10 \mu \mathrm{M})$ killed most of the K562 cells. Further dilutions showed a gradual decrease in toxicity until no deleterious effects were seen at $1 \mathrm{nM}$ (Figure 1). We therefore chose this concentration as a working concentration for 20PRA in subsequent experiments.

In radioprotection assays, cells preincubated with 20-PRA for $30 \mathrm{~min}$ were subjected to three doses of ${ }^{60} \mathrm{Co} \gamma$-ray radiation $(5,7.5$ and $20 \mathrm{~Gy})$ and further incubated for various times. The results of these experiments are summarized in Figure 1 and Table 1. Figure 1 shows the effect of $1 \mathrm{nM} 20$-PRA on the number of viable K562 cells both in irradiated (5 Gy) and non-irradiated samples. As expected, a decay in cell number due to irradiation relative to control without 20PRA was observed (Figure 1), corresponding to $13 \%, 57 \%$ and $67 \%$ at 0,24 and $48 \mathrm{~h}$, respectively. In cells incubated with aminothiol, there was partial protection of $58 \%$ and $11 \%$ at $24 \mathrm{~h}$ and $48 \mathrm{~h}$, respectively. At 48 $\mathrm{h}$, the radioprotection was low (0-11\%), regardless of the radiation dose (data not shown). Although 20-PRA afforded full protection at zero-time (Figure 1), its meaning is questionable since cell lethal effects due to 
radiation require a minimal period of time to become evident.

The decline in the number of cells observed at $48 \mathrm{~h}$ cannot be attributed to the radioprotector or its metabolic products, since controls in which 20-PRA was present at 48 $\mathrm{h}$ showed cell counts similar to those of untreated cells (Figure 1).

The drastic reduction in cell viability observed in irradiated cells incubated with 20PRA at $48 \mathrm{~h}$ could be explained by a combined effect of radiation and the radioprotector or its by-products. In this regard, it should be remembered that 20-PRA or its by-products remained in the culture throughout the 48-h period. In previous studies with WR1065 (N-(2-mercaptoethyl)-1,3 diaminopropane), it was shown that rejoining of single strand breaks following irradiation of $\mathrm{CHO}$ cells with 4 Gy was adversely affected when the drug was present in the culture (15). This effect was observed after 60 min of incubation at $37^{\circ} \mathrm{C}$ following irradiation. Therefore, we can expect a similar effect to occur in 20-PRA-treated cells. The apparent progressive reduction in radioprotection between 0 and $48 \mathrm{~h}$ can also be attributed to a different mechanism. Smoluk et al. (19) showed that WR-1065 inhibits DNA replication and cellular viability by binding to DNA under physiological conditions. It remains to be demonstrated whether 20-PRA interacts with DNA under these conditions.

On the other hand, Rubin et al. (13) recently showed that the protective effect of WR-1065 on vascular endothelial cells changes as a function of time. At $2 \mathrm{~Gy}$ the protective effect at $24 \mathrm{~h}$ was $81 \%$, but dropped to $55 \%$ when measured after $48 \mathrm{~h}$. Their data show that the variation in protection depends on the radiation dose.

We also compared the radioprotective effect of 20-PRA at different radiation doses (Table 1) and observed that the protective effect decreased as the radiation dose increased. At 5 Gy, 20-PRA afforded the best protective effect at $24 \mathrm{~h}$ but even at higher doses (20 Gy) the aminothiol exhibited a protective effect during the first $24 \mathrm{~h}$.

Based on these data, we investigated the antitumorigenic capacity of 20-PRA. This effect was measured by the inhibition of crown gall formation on potato discs induced by Agrobacterium tumefaciens (20). The results (data not shown) showed that 0.1 $\mu \mathrm{M}$ 20-PRA $\left(\mathrm{LC}_{50} / 100\right)$ inhibits $95 \%$ of crown gall formation. This high inhibition supports the view that aminothiols also have antitumorigenic activity.

Perhaps the most tempting feature of 20-PRA is the low concentration required for the radioprotective activity to become evident. Thus, while most aminothiols display a radioprotective action at 0.1 to 1.0 $\mathrm{mM}, 20-P R A$ is effective at $1 \mathrm{nM}$. For instance, the aminothiol WR-1065 at $2.0 \mathrm{mM}$ partially suppressed single strand breaks, double strand breaks and restored cell replication of irradiated endothelial cells (13). In this regard, Smoluk et al. (21) observed that WR-1065-mediated $\gamma$-radioprotection against cell killing afforded maximum protection when intracellular levels reached 7-10 nM. Assuming free diffusion of 20-PRA across the membrane we would expect intracellular levels similar to those required by WR-1065 to exert its protective action. Free diffusion

Table 1 - Effect of $1 \mathrm{nM} 20$-PRA as a radioprotective agent at various radiation doses. K562 cells were seeded into culture flasks at a density of $1.5 \times 10^{4} \mathrm{cells} / \mathrm{ml}$. One $\mathrm{nM}$ 20-PRA was then added and the cells were further incubated for $30 \mathrm{~min}$ in a $\mathrm{CO}_{2}$ incubator at $37^{\circ} \mathrm{C}$. Cells were irradiated with 5-, 7.5- and 20-Gy doses and counted after a 24-h incubation period. Data are reported as mean \pm SEM $(\mathrm{N}=3-7$ experiments). a vs $\mathrm{b}, \mathrm{P}=0.005 ; \mathrm{a}$ vs $\mathrm{c}, \mathrm{P}=0.07$; $\mathrm{b}$ vs $\mathrm{c}, \mathrm{P}=0.02$; vs $\mathrm{d}, \mathrm{P}=0.01$; vs $\mathrm{e}, \mathrm{P}=$ $0.03 ; \mathrm{d}$ vs $\mathrm{e}, \mathrm{P}=0.003$; a vs $\mathrm{f}, \mathrm{P}=0.04 ; \mathrm{a}$ vs $\mathrm{g}, \mathrm{P}=0.006 ; \mathrm{f}$ vs $\mathrm{g}, \mathrm{P}=0.12$ (Student $t$ test).

\begin{tabular}{|c|c|c|c|c|}
\hline \multirow{2}{*}{$\begin{array}{l}\text { Radiation } \\
\text { dose (Gy) }\end{array}$} & \multicolumn{4}{|c|}{ Remaining cell number/ml } \\
\hline & $\begin{array}{l}\text { Control with } \\
20-P R A\end{array}$ & Irradiated & $\begin{array}{l}\text { Irradiated + } \\
\text { 20-PRA }\end{array}$ & Protection (\%) \\
\hline 5 & $\mathrm{a}_{2.1} \pm 0.07 \times 10^{4}$ & b9.1 $\pm 1.7 \times 10^{3}$ & $c_{1.6} \pm 0.08 \times 10^{4}$ & 58 \\
\hline 7.5 & a $2.1 \pm 0.07 \times 10^{4}$ & $\mathrm{~d}_{4.1} \pm 0.83 \times 10^{3}$ & $e_{1.2} \pm 0.08 \times 10^{4}$ & 47 \\
\hline 20 & $\mathrm{a}_{2.1} \pm 0.07 \times 10^{4}$ & ${ }^{f} 4.2 \pm 0.3 \times 10^{3}$ & $g_{1} .0 \pm 0 \times 10^{4}$ & 35 \\
\hline
\end{tabular}


of the drug across the membrane is possible since 20-PRA bears no phosphate group, in contrast to WR-2721, the precursor of WR1065. These findings may have relevant implications for 20-PRA regarding its potential protective role when the cell is damaged by anticancer therapy. In this regard, tumoral cells are preferential targets for irradiation and alkylating agents because of their reduced glutathione levels which impair the removal of free radicals (22). This preliminary report refers to results obtained for 20PRA while clinical trials are in progress to evaluate radio- and chemoprotection of the aminothiols WR-2721 and WR-151327 (23).

\section{References}

1. Yuhas JM, Spellman JM \& Culo F (1980). The role of WR2721 in radiotherapy and/ or chemotherapy. Cancer Clinical Trials, 3: 211-216.

2. Scheive K \& Cox D (1988). Mammary carcinoma developing after radiotherapy and chemotherapy from Hodgkin's disease. Cancer, 61: 252-254.

3. Grdina DJ, Nagy B, Hill C, Wells RL \& Peraino C (1985). The radioprotector WR1065 reduces radiation induced mutations at the HGRPT locus in V79 cells. Carcinogenesis, 6: 929-931.

4. Grdina DJ, Peraino C, Carnes BA \& Hill CK (1985). Protective effect of S-2-(3-aminopropylamino)ethylphosphorothioic acid against induction of altered hepatocyte foci in rats treated once with $\gamma$-radiation within one day after birth. Cancer Research, 45: 5379-5381.

5. Milas L, Hunter B, Reid BO \& Thames HD (1982). Protective effects of S-2-(3-aminopropylamino)-ethylphosphorothioic acid against radiation damage of normal tissues and a fibrosarcoma in mice. Cancer Research, 42: 1888-1897.

6. Cesarone CF, Scovassi AI, Scarabelli L, Izzo R, Orunesu M \& Bertazzoni U (1988). Depletion of adenosine diphosphate-ribosyl transferase activity in rat liver during exposure to N-2-acetylaminofluorene: effect of thiols. Cancer Research, 48: 35813585.

7. Grdina DJ, Carnes BA, Grahn D \& Sigdestad CP (1991). Protection against late effects of radiation by S-2-(3-aminopropylamino)-ethylphosphorothioic acid. Cancer Research, 51: 4125-4130.

8. Purdie JW, Inhaber ER, Schnider H \& Labelle JL (1983). Interaction of cultured mammalian cells with WR 2721 and its thiol WR-1065: Implications for mechanism of radioprotection. International Journal of Radiation Biology, 43: 517-527.

9. Roots R \& Okada S (1972). Protection of DNA molecules of cultured mammalian cells from radiation-induced single-strand scissions by various alcohols and $\mathrm{SH}$ compounds. International Journal of Radiation Biology, 21: 329-342.

10. Zheng S, Newton GL, Gonick G, Fahey RC \& Ward JF (1988). Radioprotection of DNA by thiols: Relationship between the net charge on a thiol and its ability to protect DNA. Radiation Research, 114: 11-27.

11. Chapman JD, Reuvers AP, Borsa J \& Greenstock CL (1973). Chemical radioprotection and radiosensitization of mammalian cells growing in vitro. Radiation Research, 56: 291-306.

12. Ward JF (1983). Chemical aspects of DNA radioprotection. In: Nygaard OF \& Simic MG (Editors), Radioprotectors and Anticarcinogens. Academic Press, New York, 73-85.

13. Rubin DB, Drab EA, Kang HJ, Baumann FE \& Blazek ER (1996). WR-1065 and radioprotection of vascular endothelial cells. I. Cell proliferation, DNA synthesis and damage. Radiation Research, 145: 210-216.

14. Issels RD \& Nagele A (1989). Promotion of cystine uptake, increase of glutathione biosynthesis and modulation of glutathione status by S-2-(3-aminopropylamino)-ethylphosphorothioic acid (WR-2721) in Chinese hamster cells. Cancer Research, 49: 2082-2086.

15. Murray D, van Ankeren SC, Milas L \&
Meyn R (1988). Radioprotective action of WR-1065 on radiation-induced DNA strand breaks in cultured Chinese hamster ovary cells. Radiation Research, 113: 155-170.

16. Davidson DE, Grenan MM \& Sweeney TR (1980). Biological characteristics of some improved radioprotectors. In: Brady LW (Editor), Radiation Sensitizers: Their Use in the Clinical Management of Cancer. Masson, New York, 309-320.

17. Meyer BN, Ferrigni NR, Putnam JE, Jacobsen LB, Nichols DE \& McLaughlin L (1982). Brine shrimp: a convenient general bioassay for active plant constituents. Planta Medica, 45: 31-34.

18. Finney DJ (1976). Probits Analysis. 3rd edn. University Press, Cambridge.

19. Smoluk GD, Fahey RC \& Ward JF (1986). Equilibrium dialysis studies of the binding of the radioprotector compounds to DNA. Radiation Research, 107: 194-205.

20. Galsky AG, Wilsey JP \& Powell RG (1980). Crown gall tumor disc biossay. Plant Physiology, 65: 184-185.

21. Smoluk GD, Fahey RC, Calabro-Jones PM, Aguilera JA \& Ward JF (1988). Radioprotection of cells in culture by WR-2721 and derivatives: Form of drug responsible for protection. Cancer Research, 48: 36413647.

22. Oberley LW \& Buether GR (1979). Role of superoxide dismutase in cancer: a review. Cancer Research, 39: 1141-1149.

23. Green D, Bensely D \& Schein P (1994). Preclinical evaluation of WR-151327: an orally active chemotherapy protector. Cancer Research, 54: 738-741. 